\title{
Human papillomavirus 18 E6 inhibits phosphorylation of p53 expressed in HeLa cells
}

Amrendra K Ajay ${ }^{1,2}$, Avtar S Meena ${ }^{1}$ and Manoj K Bhat ${ }^{1 *}$

\begin{abstract}
Background: In HPV infected cells p53 function is abrogated by E6 and even ectopically expressed p53 is unable to perform tumor suppressor functions. In addition to facilitating its degradation, E6 may also inhibit p53 transactivity, though the mechanisms are still poorly understood. It has been reported that inhibition of p300, an acetyltransferase responsible for p53 acetylation is inactivated by E6. Activation of overexpressed p53 to cause cell growth inhibition is facilitated by its phosphorylation. Previously, we reported that non-genotoxically overexpressed p53 in HeLa cells needs to be phosphorylated to perform its cell growth inhibitory functions. Since over expressed p53 by itself was not activated, we hypothesized an inhibitory role for E6.
\end{abstract}

Results: Majority of reports proposes E6 mediated degradation of p53 as a possible reason for its inactivation. However, results presented here for the first time demonstrate that overexpressed p53 is not directly associated with E6 and therefore free, yet it is not functionally active in HPV positive cells. Also, the stability of overexpressed p53 does not seem to be an issue because inhibition of proteasomal degradation did not increase the half-life of overexpressed p53, which is more than endogenous p53. However, inhibition of proteasomal degradation prevents the degradation of endogenous p53. These findings suggest that overexpressed p53 and endogenous p53 are differentially subjected to proteasomal degradation and the reasons for this discrepancy remain unclear. Our studies demonstrate that p53 over expression has no effect on anchorage independent cell-growth and E6 nullifies its cell growth inhibitory effect. E6 overexpression abrogates OA induced p53 occupancy on the p21 promoter and cell death as well. E6 did not decrease p53 protein but phospho-p53 level was significantly reduced.

Conclusion: We report for the first time that E6 de-activates p53 by inhibiting its phosphorylation. This prevents p53 binding to p21 promoter and thereby restraining its cell-growth inhibitory functions. Our study provides new evidence indicating that viral protein E6 inhibits p53 transactivity by mechanism independent of degradation pathway.

Keywords: HPV, p53, phosphorylation, cervical cancer, E6

\section{Background}

Approximately 470,000 new cases of cervical cancer are diagnosed every year and close to 230,000 women worldwide die, with the majority $(\sim 80 \%)$ of incidence occurring in developing countries. Human papillomavirus (HPV) infection is the main causative agent for cervical cancer. Reports suggest that $99.7 \%$ of cervical cancers harbor integrated HPV DNA in host cell genome [1]. HPV presence is reported in $5-11 \%$ of oral cancers [2]. In head and neck cancers the percentage of HPV infection is low and it accounts for 11-25\% [3-8].

\footnotetext{
* Correspondence: manojkbhat@nccs.res.in

'National Centre for Cell Science, NCCS Complex, Pune University Campus,

Ganeshkhind, Pune - 411007, India

Full list of author information is available at the end of the article
}

In developed countries $50-70 \%$ of oropharyngeal and tonsillar carcinomas are associated with HPV infection $[9,10]$. Papillomaviruses are also reported to be present in colon and $90 \%$ of anal cancers [11-14]. HPVs are classified in two categories, low risk, which has less or no potential and high risk, which has potential to cause carcinogenesis. HPV 16 and 18 are high risk HPVs, accounting for more than $50 \%$ of cervical cancers and are considered as a major cause of other (head and neck as well as anal) cancers too.

The two onco-proteins of HPV, E6 and E7 cause transformation, immortalization and promote carcinogenesis primarily by binding to important tumor suppressor's p 53 and $\mathrm{pRb}$, thereby completely deregulating cell cycle checkpoints [15-18]. E6 and E7 alone can also immortalize,

\section{Biomed Central}


deregulate cell cycle and cause transformation of even primary cultures [19-21]. E6 degrades p53 by E3 ubiquitin dependent and independent proteasomal degradation $[18,22]$.E6 also inhibits p53 transactivity by inhibiting acetylation [23], because of its ability to bind directly and degrade p300, an important acetyltransferase [24,25]. To completely abrogate p53 activity E6 also degrades bax, a major p53 downstream apoptosis inducer [26]. It has been reported that inhibition of E6 by its specific siRNA reactivates dormant p53 pathways, and the mechanisms by which functions are restored are not clear [27-29].

Activation of many proteins is accomplished by phosphorylation, which is caused by group of enzymes called kinases [30]. Concomitantly, activated proteins are kept under check by phosphatases, thus opposing the effects of kinases [31]. p53 being a phospho-protein is trans-activated by phosphorylation and deactivated by dephosphorylation [32]. Okadaic acid (OA), a specific inhibitor of protein phosphatases, promotes phosphorylation of p53 or its upstream kinases at various residues [33,34]. Recently, we reported that OA activates overexpressed p53, causing cell cycle arrest and apoptosis in HeLa cells [35]. Very little is known about the phosphorylation status of p53 in response to its silencing by E6, except for one study which reported that p53 is phosphorylated at multiple residues by transiently transfected E6 [36]. In the present investigation we demonstrate that upon OA treatment overexpressed p53 is phosphorylated at serine 46 residue and ectopic expression of E6 promotes its dephosphorylation. Our study provides new evidence indicating that viral protein E6 inhibits p53 transactivity by mechanism independent of degradation pathway.

\section{Results}

\section{Over expression of p53 in HeLa cells}

Earlier we reported the development of HeLa cells in which p53 is conditionally overexpressed and induction of p53 is tightly regulated by doxycycline (DOX) in a dose dependent manner. Two p53 expressing clones (HTet23p53 and HTet26p53) and one GFP expressing clone (HTet43GFP) were used in this study [35]. Dox in a dose dependent manner induces p53 protein in both HTet23p53 (Figure 1A) and HTet26p53 (Figure 1B) cells as compared to HTet43GFP cells (Figure 1C). Densitometric analysis of bands in these blots suggests that in comparison with non-induced state, more than 5 fold increases in p53 level was achieved in the presence of $2000 \mathrm{ng} / \mathrm{ml}$ Dox (Figure 1D). No alteration in p53 level was detected in HTet43GFP cells (Figure 1C) cells under identical experimental conditions.

\section{p53 is expressed in a time dependent manner}

To study the kinetics of p53 expression single dose $(1000 \mathrm{ng} / \mathrm{ml})$ of Dox was added for different time durations ( $1 \mathrm{~h}$ to $48 \mathrm{~h}$ ) and western blot was performed. As shown in Figure 2, p53 expression was initiated within $1 \mathrm{~h}$ of Dox addition and it increased progressively up to $48 \mathrm{~h}$ of incubation in HTet23p53 (Figure 2A) and HTet26p53 cells (Figure 2B). No changes in basal p53 levels were detected in HTet43GFP (Figure 2C) cells under identical experimental conditions. At 48 h, 5-fold increase in p53 protein was detected in HTet23p53 and HTet26p53 cells as compared to HTet43GFP cells (Figure 2D).

\section{Overexpressed p53 has no effect on anchorage independent growth}

The tumorigenic potential of p53 overexpressing cells was assessed by soft agarose assay, which is often used method for characterization of cellular growth properties. In HTet23p53 (Figure 3A) as well as HTet26p53 (Figure 3B) cells; no decrease in anchorage independent growth was detected even after inducing p53 with upto $2000 \mathrm{ng} / \mathrm{ml}$ Dox. HTet43GFP cells served as control (Figure $3 \mathrm{C}$ ). No significant difference in the colony number and size of p53 overexpressing clones as compared to GFP expressing clone was visible. Dox treatment slightly decreased colony number in all the three cell lines, which may be because of long term Dox cytotoxicity.

\section{Overexpressed p53 is stable}

To perform tumor suppressor functions p53 stability is essential. Therefore to ascertain that overexpressed p53 is stable and it is not degraded by E6, cycloheximide (Chx) chase experiment was performed. Cells were treated with Chx for different time points to inhibit protein synthesis and then western blotted to detect p53. In the presence of Chx over expressed p53 was present in significant amount in HTet23p53 and HTet26p53 cells (Figure 4A and 4B) even after $6 \mathrm{~h}$. Under these experimental conditions endogenous p53 in same cells (Figure $4 \mathrm{~A}$ and $4 \mathrm{~B}$ ) or in HTet43GFP cells (Figure 4C) decreased to undetectable levels just within $1 \mathrm{~h}$. The half-life of overexpressed p53 was calculated to be $6 \mathrm{~h}$ as compared to that of less than $1 \mathrm{~h}$ for endogenous p53 (Figure 4D).

\section{Inhibition of proteasome promotes stability of endogenous p53 but not for ectopically overexpressed p53}

It is very well known that p53 undergoes proteasomal degradation. Inhibiting proteasomal degradation by two specific inhibitors MG132 and lactacystin did not cause accumulation of overexpressed p53 protein in HTet23p53 as well as HTet26p53 cells upto $3 \mathrm{~h}$. Treatment with these inhibitors prevents degradation of endogenous p53 protein in HTet23p53, HTet26p53 and 


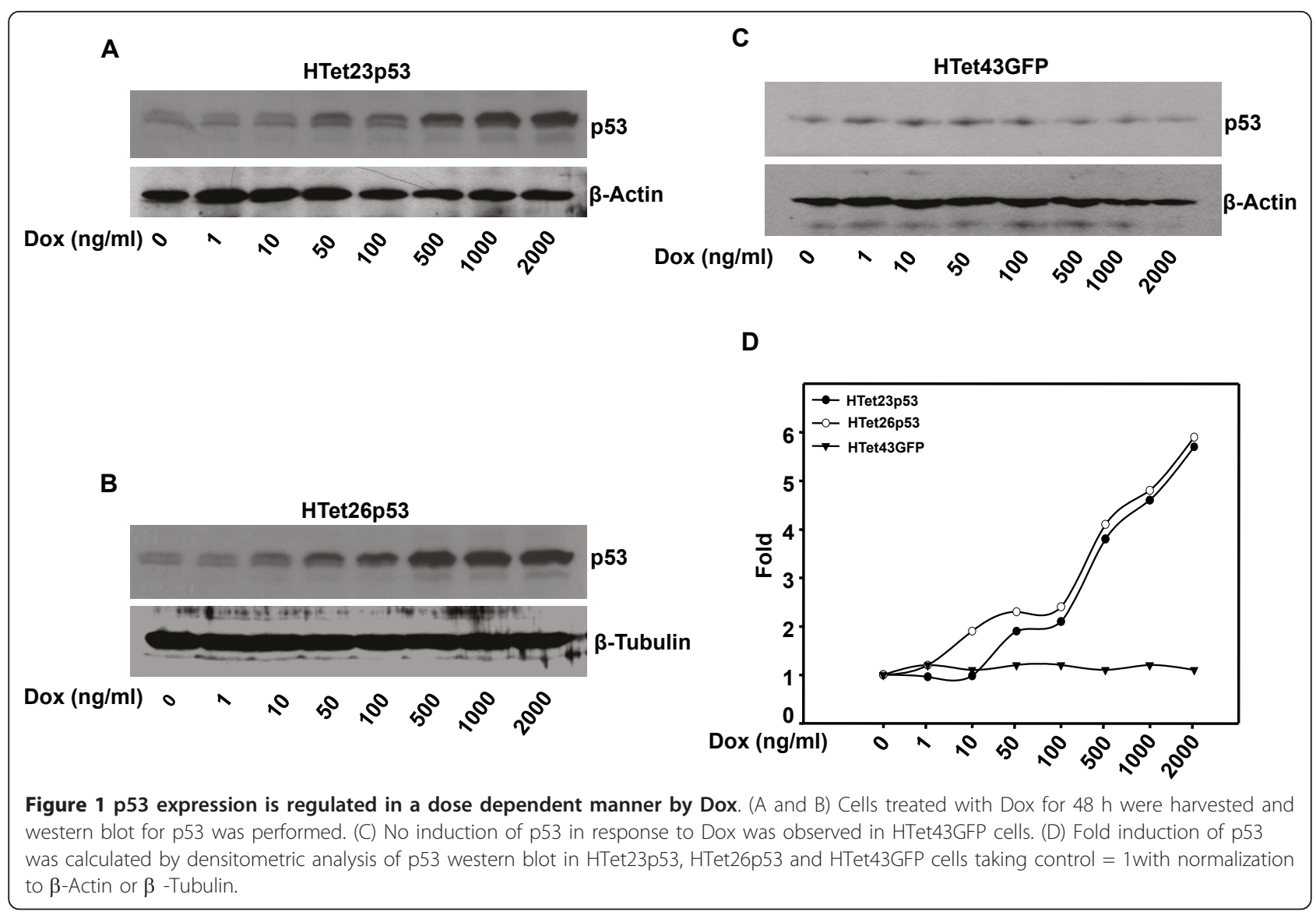

HTet43GFP cells even after Chx chase for $1 \mathrm{~h}$ (Figure $5 \mathrm{~A}$ and $5 \mathrm{~B})$. Taken together these results suggest that endogenousp53 is stabilized in the presence of inhibitors whereas overexpreseed p53 levels are not altered.

Inhibition of protein phosphatase $2 \mathrm{~A}$ promotes cell death and $\mathrm{E} 6$ reverses it by inhibiting promoter occupancy of activated overexpressed p53

To determine whether E6 inhibits activity, p53 was first activated by $5 \mathrm{nM} \mathrm{OA}$, a protein phosphatase $2 \mathrm{~A}$ (PP2A) inhibitor. As a consequence of p53 activation cell growth is retarded in p53 overexpressing HTet23p53 and HTet26p53 cells compared to p53 nonoverexpressing HTet23p53, HTet26p53 or HTet43GFP cells. Cell survival inhibitory effect was abolished by ectopic expression of HPV 18 E6 in OA treated p53 overexpressing cells (Figure 6A). Overexpressed p53 is not completely associated with E6 and ectopic expression of E6 does not further enhance this association, though p53 is detected in co-immunoprecipitated complex (Figure 6B). To confirm the presence of free p53 in the lysate immunoprecipitated by E6 antibody (first IP), second immunoprecipitation with p53 (FL-393) was done. Interestingly, ectopic expression of E6 did not affect the p53 protein but it does drastically decrease the level of Ser46 phosphorylated p53 (pSer46p53) (Figure $6 \mathrm{C}$ ). Further, to confirm that E6 mediated inhibition of p53 phosphorylation actually is responsible for cell growth inhibition, we performed luciferase reporter activation assay for well-known transcriptional target p21. p21 promoter was activated by OA treatment and E6 over expression inhibits promoter activation (Figure 6D).

\section{Overexpression of p53 causes cell death and E6} expression promotes cell survival in p53/E6 null lung carcinoma cell line

To investigate the consequences of direct functional interaction between p53 and E6 we transfected wild type-p53 with or without E6 in H1299 lung carcinoma cells, which are null for p53, and E6. p53 overexpression decreases cell survival by 25 percent confirming it being active in non HPV cells. OA enhances activity of p53 and therefore cell survival decreases further by additional 25 percent. Co-expression of HPV18E6 in p53 expressing cells treated with or without OA promotes survival (Figure 7A). At protein level, as expected no p53 is detected in these cells and it is expressed in cells transfected with p53 plasmid. Interestingly, co- 


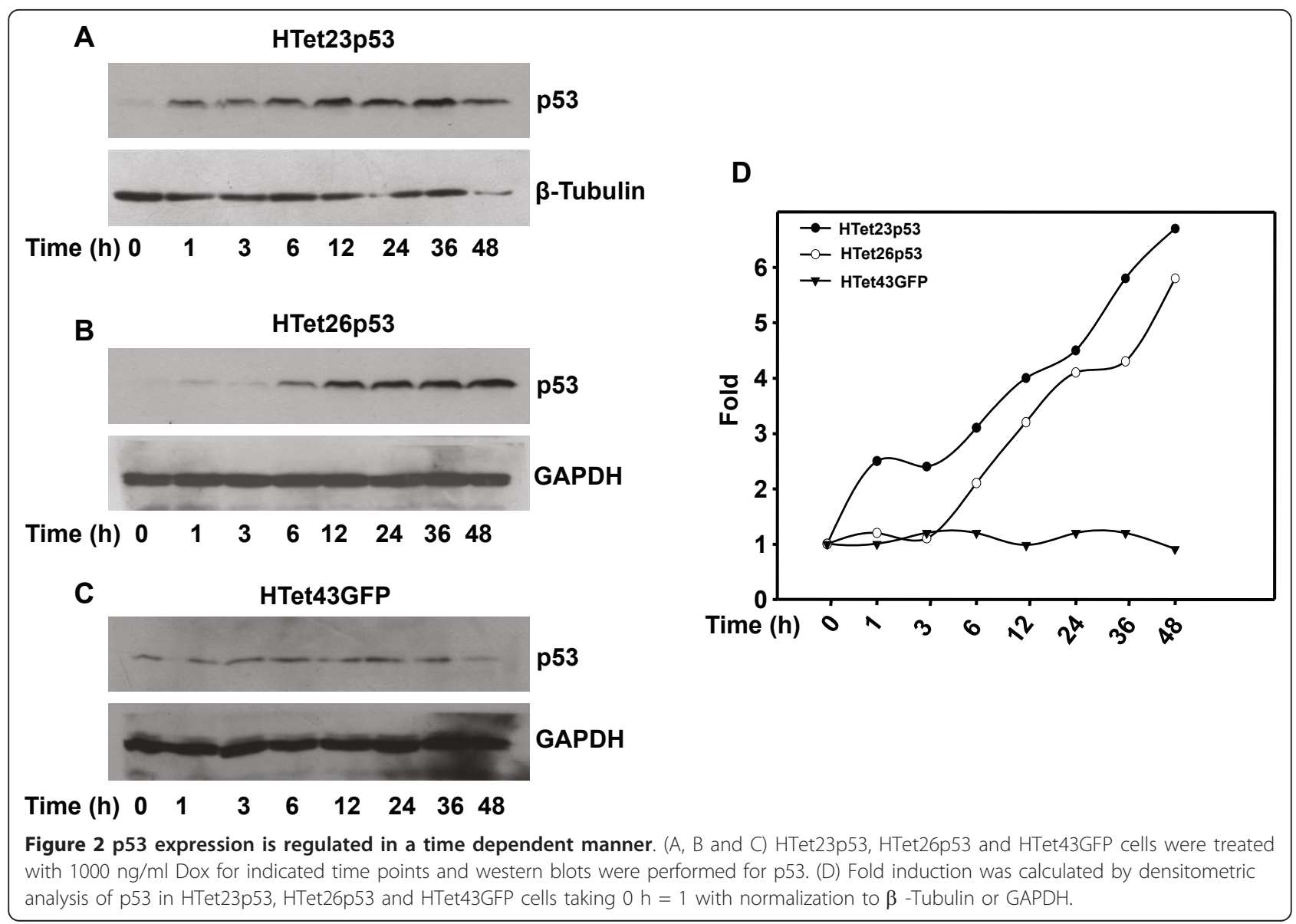

transfection with HPV18E6 construct reduces p53 levels below detection in non OA treated cells, whereas in OA treated cells p53 is detected. Reduction of p53 level (Figure 7B, Lane 5) may be due to its degradation by E6. Comparatively, the protein levels are higher in OA treated cells with or without E6. OA treatment enhances pSer46p53 levels (Figure 7B, Lane 4) and E6 diminishes OA promoted phosphorylation (Figure 7B, Lane 6). Also, phosphorylated p53 levels decrease in the presence of E6 (Figure 7B, Lane 6).

\section{Discussion}

p53 overexpression in HeLa cells does not exhibit cell growth inhibitory functions whereas in non HPV positive H1299 cells it causes cell death (unpublished observation). This difference in p53 activity is likely to be dependent on the appropriate post-translational modifications including phosphorylation status, which depends on host cell phenotype. Also, E6 overexpression has differential effect on p53 protein stability. In HeLa cells it does not degrade p53 but in H1299 it completely degrades it.
Others and we reported that activation of overexpressed p53 to cause cell growth inhibition is facilitated by its phosphorylation at Ser46 [35-37]. Majority of reports suggest the E6 or E7 mediated degradation/functional impairment of p53 as possible reason for its inactivation [38-40]. However, for the first time results presented here demonstrate that overexpressed p53 is not directly associated with E6 and therefore free, yet it is not functionally active in HPV positive cells. Also, overexpressed p53 has significantly increased half life and proteasomal inhibitors do not exhibit any detectable impact on the levels of overexpressed p53. These results suggest that it is likely p53 activation might be inhibited by yet unknown mechanism.

Ectopic expression of E6 does not decrease overexpressed p53 protein level in HeLa and H1299 cells treated with OA, which could be because of swamping out of the available E6 and/or E6AP. This proposition derives support from a report describing the involvement of an E6 associated protein (E6 AP), which forms a ternary complex essential for ubiquitination of p53 [41]. It is also possible that the post-translational 


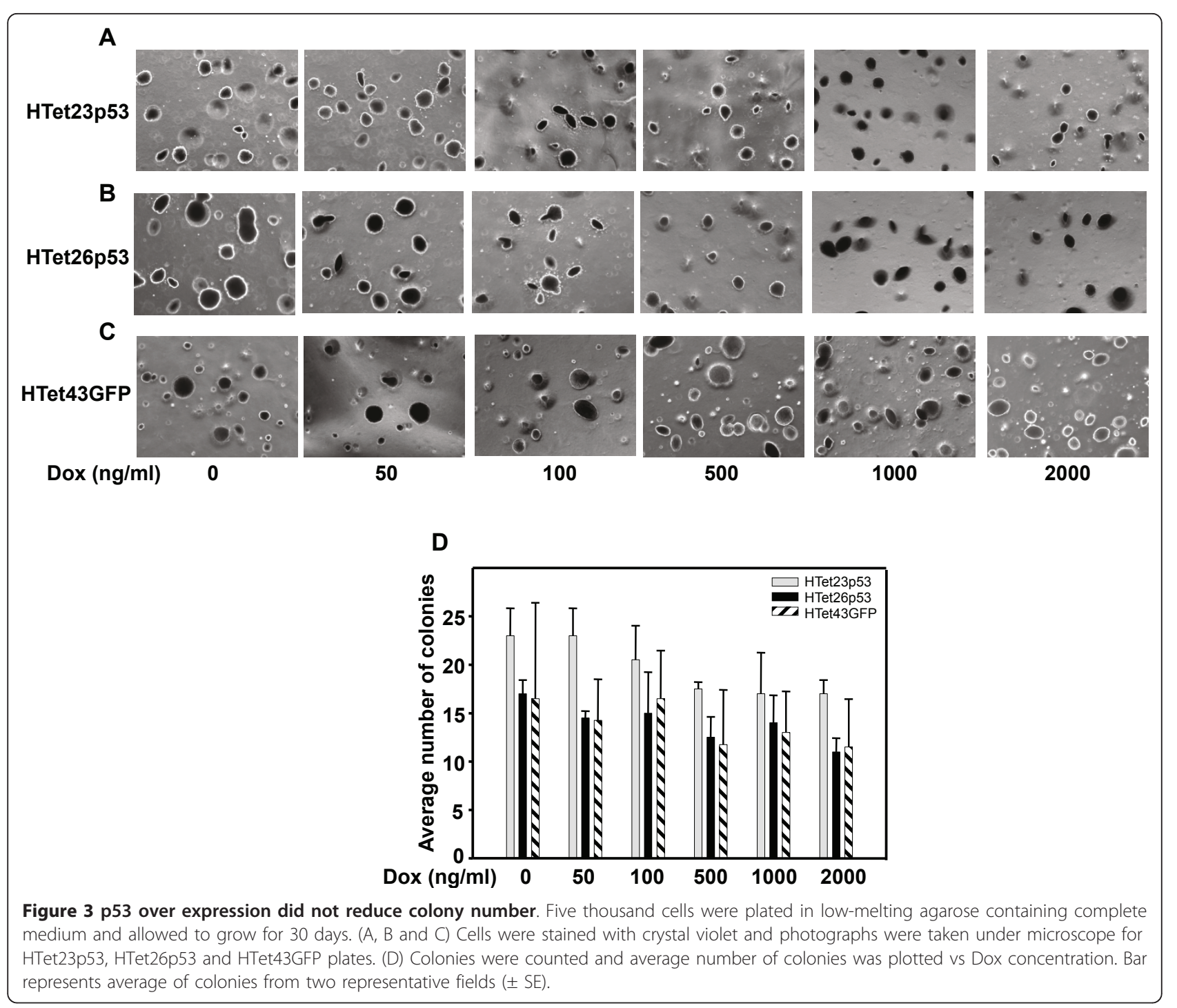

modification as well as conformation of overexpressed p53 might be different and is therefore not recognizable by the E6 and E6AP complex. The involvement of specific post-translational alterations is consistent with our [35] and other reports [37,42]. Together, these results suggest that expressed p53 is activated only in the presence of PP2A inhibitor and p53 phosphorylation at a key residue is very critical for specific DNA binding as well as promoter selection under various stress conditions. Interestingly, p53 phosphorylation is diminished by over expression of E6 in HeLa cells (Figure 6C), which indicates that $\mathrm{E} 6$ causes inactivation of $\mathrm{p} 53$ by inhibiting its phosphorylation. Also, E6 expression significantly inhibits p21 promoter occupancy of the overexpressed and activated p53, which has an impact on cell growth (Figure 6D and 6A). Further, to confirm this hypothesis we utilized p53 and E6 null H1299 cells.
Overexpression of p53 causes cell death (Figure 7A), which parallels with p53 and pSer46p53 levels. OA treatment further enhances cell killing by stabilizing $\mathrm{p} 53$ and pSer46p53 levels. Interestingly, E6 coexpression causes complete degradation of p53 in non-OA treated cells whereas in OA treated cells E6 does not reduce p53 levels though it decreases pSer46p53 level (Figure 7B), which correlates with increased cell survival under these condition (Figure 7A). Future studies with small molecule activator like PRIMA that activates mutant p53, [43] will be useful in delineating the mechanisms of p53 activation.

\section{Conclusion}

The results presented here provide insight into differential regulation of endogenous and exogenous p53 and the role HPV E6 plays in its phosphorylation and 


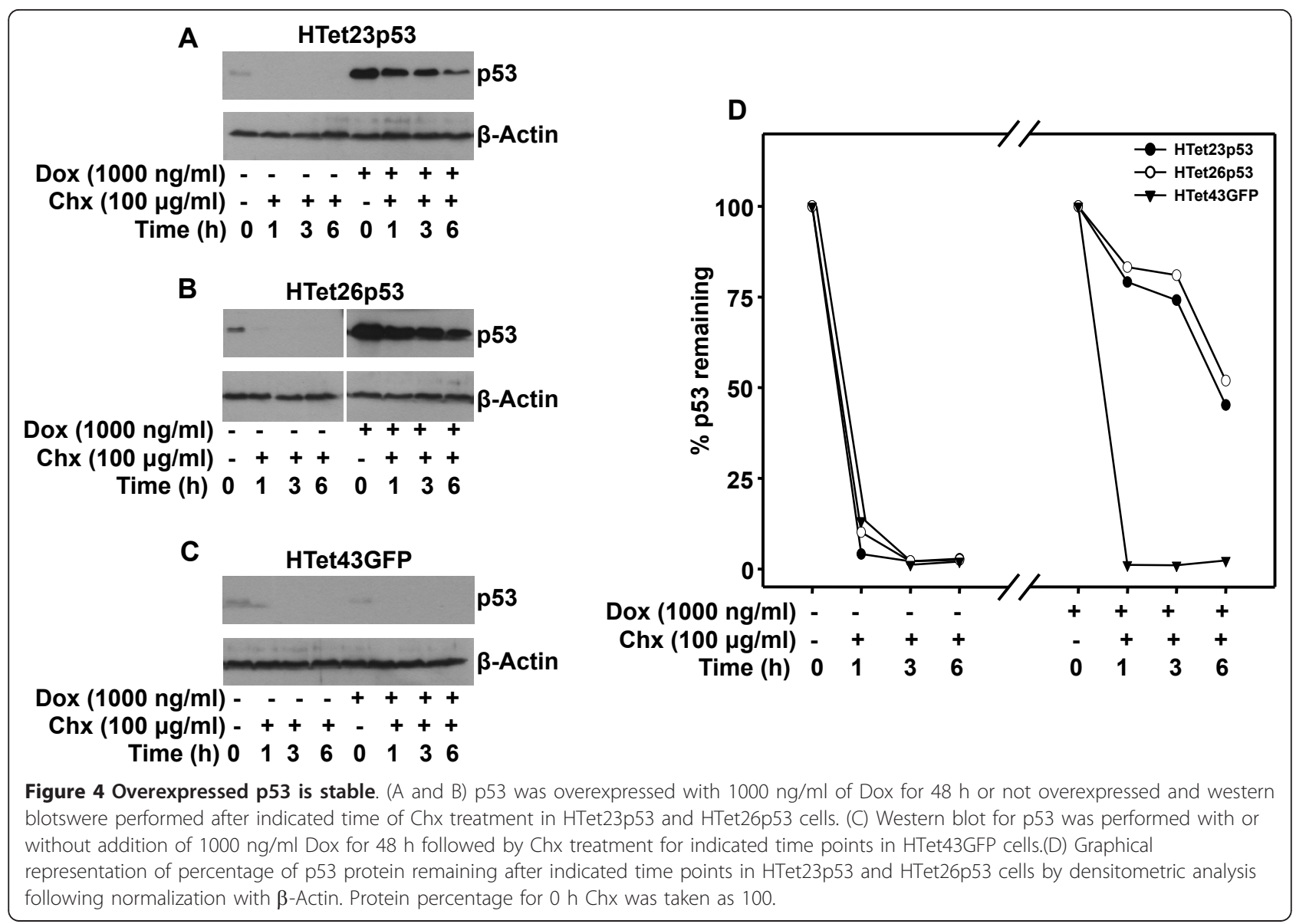

activation. These findings imply that replacement of degraded, mutated p53 protein or functionally inactivated $\mathrm{p} 53$ with the wild-type one will have significant therapeutic importance only when its activation is also achieved simultaneously. The functionality of p53 depends on the cellular background.

\section{Materials and methods}

\section{Chemicals and antibodies}

Doxycycline (Dox) and cycloheximide was purchased from Sigma (St. Louis, MO). Tet-system approved serum and Hygromycin solution $(50 \mathrm{mg} / \mathrm{ml})$ was purchased from BD (Mountain View, CA). G418 was purchased from (USB, OH). Antibodies against p53 (FL-393 goat polyclonal; DO1-HRP conjugated mouse monoclonal), E6 (goat polyclonal and mouse monoclonal), GAPDH (goat polyclonal), $\beta$-Tubulin (rabbit polyclonal) and $\beta$-Actin (goat polyclonal) were purchased from Santa Cruz Biotechnology (Santa Cruz, CA). MG132 and Lactacystin were purchased from Calbiochem (CA). Okadaic acid (OA) was purchased from Invitrogen Corporation. Phospho-p53 Ser46 antibody (rabbit polyclonal) was purchased from Cell Signaling Technology
(Danvers, MA). HRP conjugated secondary antibodies were purchased from Santa Cruz Biotechnology.

\section{Cell lines}

HeLa and H1299 cell lines were purchased from American Type Culture Collection (Manassas, VA) and maintained in our in-house National Cell Repository, National Centre for Cell Science (NCCS), Pune, India. Dox inducible cell lines were developed by utilizing BD-TetOn system and stably transfecting with pTetOn and pTREp53 or pBIEGFP. Dulbecco's minimum essential medium (DMEM) was purchased from Invitrogen Corporation. The inducible cell lines were regularly cultured in DMEM, supplemented with $10 \%$ Tet system approved fetal bovine serum at $37^{\circ} \mathrm{C}$ with $5 \% \mathrm{CO}_{2}$. Inducible cell lines were maintained in 100 $\mu \mathrm{g} / \mathrm{ml}$ of $\mathrm{G} 418$ and $50 \mu \mathrm{g} / \mathrm{ml}$ of hygromycin.

\section{Plasmids and transfection}

pTet-On, pTRE, pTK-Hyg and pBIEGFP were purchased from BD. pC53-SN3 (p53 plasmid) was a kind gift from Dr. Bert Vogelstein, John Hopkins, Baltimore, MD USA. p53 fragment of pC53-SN3 was sub-cloned in BamH1 site of pTRE and was renamed as pTREp53. p21 


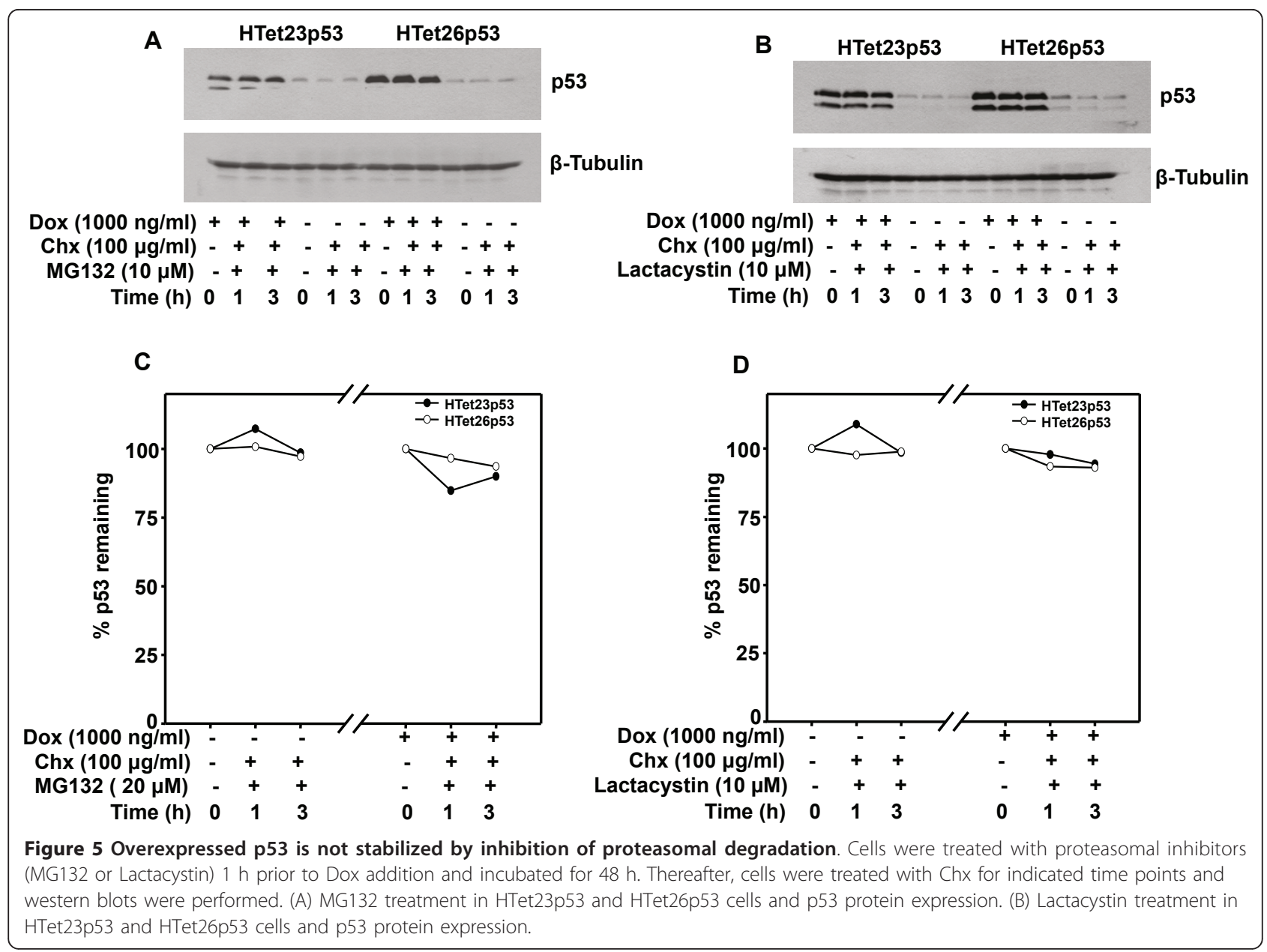

luciferase was kind gift from Dr. Bert Vogelstein. pFLAG-HPV 18 E6 plasmid was kind gift from Dr. McCance DJ, University of Rochester, USA.

Transfections were performed by Lipofectamine2000 (Invitrogen) as per manufacture's protocols.

\section{Soft agarose assay}

Culture dish was layered with $1 \mathrm{ml}$ of $0.7 \%$ agarose. Five thousand HTet23p53, HTet26p53 and HTet43GFP cells were plated in $0.5 \%$ low melting agarose (FMC Bioproducts, ME) containing DMEM and 10\% FBS with or without Dox and incubated after layering with $1 \mathrm{ml} \mathrm{com-}$ plete medium. Medium containing indicated concentration of Dox was changed every $4^{\text {th }}$ day. After 30 days plates were stained with $0.1 \%$ crystal violet for $1 \mathrm{~h}$ and photographed under a microscope. Colonies of more than 50 cells were counted and graph was plotted from the average of two independent fields from each plates.

\section{Cell proliferation assay}

Cell proliferation was determined by methylthiazole tetrazolium (MTT) assay. Cells were seeded at the density of 7,500 per well into 96 well plates and allowed to adhere for $24 \mathrm{~h}$. Cells were transfected with pCDNA3 or HPV 18 E6 plasmid construct by Lipofectamine2000 reagent. Eighteen hour post transfection cells were washed thrice with DMEM and treated with Dox in the presence of absence of OA and further incubated for 48 h. Fifty microliter of MTT $(1 \mathrm{mg} / \mathrm{ml})$ was added to each well and incubated for $4 \mathrm{~h}$ at $37^{\circ} \mathrm{C}$. Hundred microliter of 2-propanol was added and incubated in shaking condition at room temperature for $10 \mathrm{~min}$. Absorbance was taken at $570 \mathrm{~nm}$ using $630 \mathrm{~nm}$ as reference filter. Absorbance given by untreated cells was considered as $100 \%$ cell survival.

\section{Preparation of whole cell lysate and western blotting}

Following indicated treatments, cells were washed thrice with ice-cold phosphate buffered saline (PBS) and lysed in ice-cold lysis buffer (50 mM Tris-Cl, pH 7.5, with $120 \mathrm{mM} \mathrm{NaCl}, 10 \mathrm{mM} \mathrm{NaF}, 10 \mathrm{mM}$ sodium pyrophosphate, $2 \mathrm{mM}$ EDTA, $1 \mathrm{mM} \mathrm{Na} \mathrm{VO}_{4}, 1 \mathrm{mM}$ PMSF, $1 \%$ NP-40 and protease inhibitor cocktail (Roche Diagnostics, Germany). Equal amount of protein was resolved 


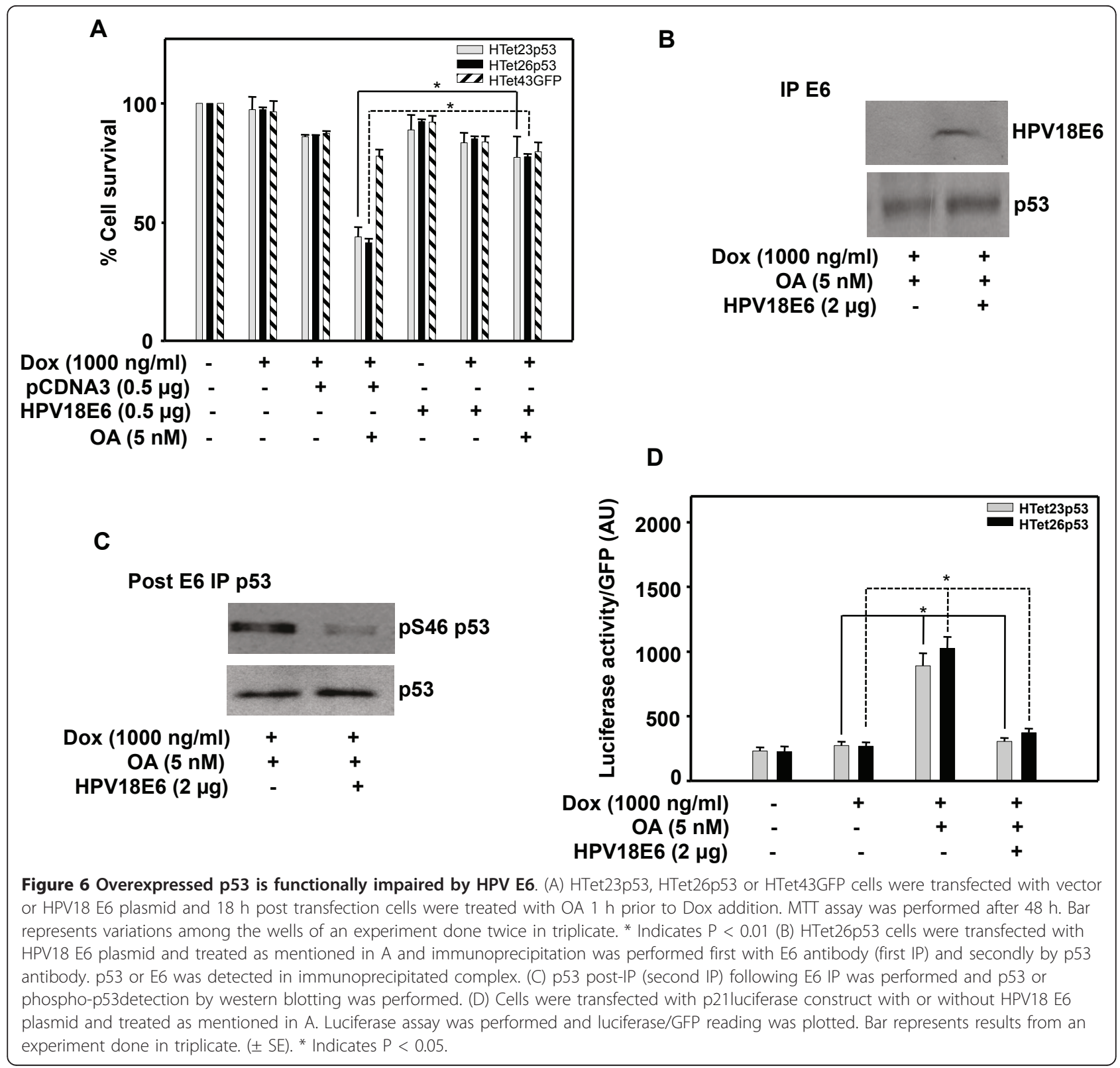

on SDS-PAGE and western blotting was preformed as described earlier [44]. Where ever possible blots were stripped by incubating the membranes at $50^{\circ} \mathrm{C}$ for 30 min in stripping buffer $(62.5 \mathrm{mM}$ Tris- $\mathrm{Cl} \mathrm{pH}$ 6.7, 100 $\mathrm{mM}$ mercaptoethanol, $2 \%$ SDS) with intermittent shaking. Membranes were washed thoroughly with TBS and reprobed with required antibodies. Otherwise gels run in duplicates were probed for the desired proteins by western blotting and then compiled.

\section{Cycloheximide chase assay}

HTet23p53, HTet26p53 and HTet43GFP cells grown in a $35 \mathrm{~mm}$ plate were treated with $1000 \mathrm{ng} / \mathrm{ml}$ of Dox for
$48 \mathrm{~h}$ and then $100 \mu \mathrm{g} / \mathrm{ml}$ cycloheximide (Chx) was added. Cells were further incubated for indicated time points and processed for western blotting. For inhibitor experiments cells were treated with MG132 or Lactacystin $10 \mu \mathrm{M}$ each $48 \mathrm{~h}$ prior to Chx addition and harvested after indicated time points after Chx addition.

\section{Immunoprecipitation}

After indicated treatment cells were harvested and lysed in RIPA buffer. Equal amount of protein $(400 \mu \mathrm{g})$ was taken and lysates were pre-cleared with $50 \mu \mathrm{l}$ protein $\mathrm{A} /$ $\mathrm{G}$ plus agarose (Invitrogen Corporation) for $30 \mathrm{~min}$. Agarose beads were pelleted and supernatant was 


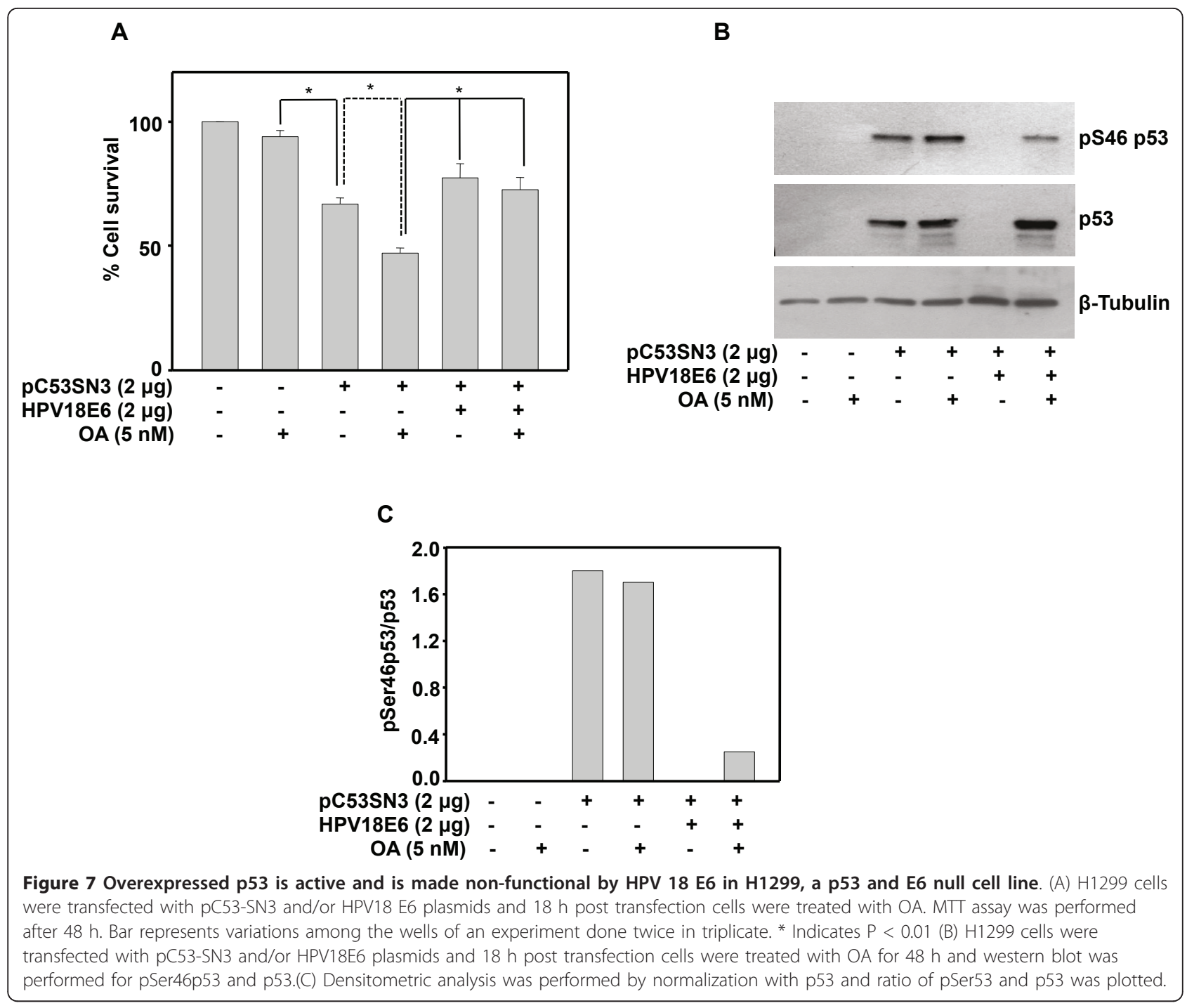

incubated with anti-E6 goat polyclonal antibody overnight at $4^{\circ} \mathrm{C}$ in an IP rotator. Fifty microliter protein A/ $G$ plus agarose was then added in antibody-antigen complex with gentle shaking for 4-5 hours at $4^{\circ} \mathrm{C}$ (first IP). The immune complex bound to protein $A / G$ plus agarose was separated by centrifugation at $4000 \mathrm{rpm}$ and supernatant was immunoprecipitated with anti-p53 goat polyclonal antibody and as described above (second IP). Target as well as its associated proteins was disrupted from protein $\mathrm{A} / \mathrm{G}$ plus agarose beads by adding SDS gel sample buffer, resolved on SDS PAGE and processed for western blotting [44] with mouse monoclonal E6 and p53 antibodies.

\section{Luciferase assay}

Semi-confluent HTet23p53 and HTet26p53 cells plated in a 12 well plate were co- transfected with pEGFPC1 and p21 luciferase plasmids by Lipofectamine2000.
Eighteen hour post-transfection $1000 \mathrm{ng} / \mathrm{ml}$ Dox was added with or without $\mathrm{OA}$ and further incubated for 48 h. Luciferase assay was performed as per manufacturer's protocol (Amersham Biosciences). GFP reading was taken as an internal control for normalization of transfection efficiency and graphs were plotted.

\section{Statistical Analysis}

Data are expressed as the mean of three independent experiments. Statistical comparisons are made using two tailed students paired t-test by assuming variance is unequal (SPSS Inc, USA) and $P$ value $<0.05$ was considered as significant.

\section{List of Abbreviations}

Dox: doxycycline; HPV: human papillomavirus; OA: okadaic acid; PP2A: protein phosphatase $2 \mathrm{~A}$. 


\section{Acknowledgements}

We thank Department of Biotechnology, Government of India, for providing research funding. A.K.A thanks Indian Council for Medical Research. A.S.M. thanks Council of Scientific and Industrial Research for fellowship. Support from other group members and all technical staff of NCCS is also duly acknowledged.

\section{Author details}

'National Centre for Cell Science, NCCS Complex, Pune University Campus, Ganeshkhind, Pune - 411007, India. ${ }^{2}$ Renal Division, Brigham and Women's Hospital, Harvard Medical School, Boston, MA, USA.

\section{Authors' contributions}

AKA and MKB designed the study. AKA performed experiments in HeLa cells and analyzed the data. ASM performed experiment with H1299 cells. AKA and MKB wrote the manuscript and MKB supervised the project. All authors read and approved the final manuscript.

\section{Competing interests}

The authors declare that they have no competing interests.

Received: 5 October 2011 Accepted: 13 January 2012

Published: 13 January 2012

\section{References}

1. Walboomers JM, Jacobs MV, Manos MM, Bosch FX, Kummer JA, Shah KV, Snijders PJ, Peto J, Meijer CJ, Munoz N: Human papillomavirus is a necessary cause of invasive cervical cancer worldwide. J Pathol 1999, 189:12-19.

2. Franceschi S, Munoz N, Bosch XF, Snijders PJ, Walboomers JM: Human papillomavirus and cancers of the upper aerodigestive tract: a review of epidemiological and experimental evidence. Cancer Epidemiol Biomarkers Prev 1996, 5:567-575

3. Brandwein M, Zeitlin J, Nuovo GJ, MacConnell P, Bodian C, Urken M, Biller H: HPV detection using "hot start" polymerase chain reaction in patients with oral cancer: a clinicopathological study of 64 patients. Mod Pathol 1994, 7:720-727.

4. Fouret P, Monceaux G, Temam S, Lacourreye L, St Guily JL: Human papillomavirus in head and neck squamous cell carcinomas in nonsmokers. Arch Otolaryngol Head Neck Surg 1997, 123:513-516.

5. Gillison ML, Koch WM, Shah KV: Human papillomavirus in head and neck squamous cell carcinoma: are some head and neck cancers a sexually transmitted disease? Curr Opin Oncol 1999, 11:191-199.

6. Snijders PJ, Scholes AG, Hart CA, Jones AS, Vaughan ED, Woolgar JA, Meijer CJ, Walboomers JM, Field JK: Prevalence of mucosotropic human papillomaviruses in squamous-cell carcinoma of the head and neck. Int $J$ Cancer 1996, 66:464-469.

7. Gillison ML, Koch WM, Capone RB, Spafford M, Westra WH, Wu L, Zahurak ML, Daniel RW, Viglione M, Symer DE, Shah KV, Sidransky D: Evidence for a causal association between human papillomavirus and a subset of head and neck cancers. J Nat/ Cancer Inst 2000, 92:709-720.

8. Gillison ML, Shah KV: Human papillomavirus-associated head and neck squamous cell carcinoma: mounting evidence for an etiologic role for human papillomavirus in a subset of head and neck cancers. Curr Opin Oncol 2001, 13:183-188.

9. Paz IB, Cook N, Odom-Maryon T, Xie Y, Wilczynski SP: Human papillomavirus (HPV) in head and neck cancer. An association of HPV 16 with squamous cell carcinoma of Waldeyer's tonsillar ring. Cancer 1997, 79:595-604.

10. Pintos J, Franco EL, Black MJ, Bergeron J, Arella M: Human papillomavirus and prognoses of patients with cancers of the upper aerodigestive tract. Cancer 1999, 85:1903-1909.

11. Coutlee F, Rouleau D, Petignat P, Ghattas G, Kornegay JR, Schlag P, Boyle S, Hankins C, Vezina S, Cote P, Macleod J, Voyer H, Forest P, Walmsley S, Franco E: Enhanced detection and typing of human papillomavirus (HPV) DNA in anogenital samples with PGMY primers and the linear array HPV genotyping test. J Clin Microbiol 2006, 44:1998-2006.

12. Heideman DA, Waterboer T, Pawlita M, Delis-van DP, Nindl I, Leijte JA, Bonfrer JM, Horenblas S, Meijer CJ, Snijders PJ: Human papillomavirus-16 is the predominant type etiologically involved in penile squamous cell carcinoma. J Clin Oncol 2007, 25:4550-4556.
13. Parkin DM, Bray F: Chapter 2: The burden of HPV-related cancers. Vaccine 2006, 24(Suppl 3):S11-S25.

14. Rubin MA, Kleter B, Zhou M, Ayala G, Cubilla AL, Quint WG, Pirog EC: Detection and typing of human papillomavirus DNA in penile carcinoma: evidence for multiple independent pathways of penile carcinogenesis. Am J Pathol 2001, 159:1211-1218.

15. Bischof O, Nacerddine K, Dejean A: Human papillomavirus oncoprotein E7 targets the promyelocytic leukemia protein and circumvents cellular senescence via the Rb and p53 tumor suppressor pathways. Mol Cell Biol 2005, 25:1013-1024.

16. Boyer $S N$, Wazer DE, Band V: E7 protein of human papilloma virus-16 induces degradation of retinoblastoma protein through the ubiquitinproteasome pathway. Cancer Res 1996, 56:4620-4624.

17. Scheffner M, Huibregtse JM, Vierstra RD, Howley PM: The HPV-16 E6 and E6-AP complex functions as a ubiquitin-protein ligase in the ubiquitination of p53. Cell 1993, 75:495-505.

18. Scheffner M, Werness BA, Huibregtse JM, Levine AJ, Howley PM: The E6 oncoprotein encoded by human papillomavirus types 16 and 18 promotes the degradation of p53. Cell 1990, 63:1129-1136.

19. Hawley-Nelson P, Vousden KH, Hubbert NL, Lowy DR, Schiller JT: HPV16 E6 and E7 proteins cooperate to immortalize human foreskin keratinocytes. EMBO J 1989, 8:3905-3910.

20. Heck DV, Yee CL, Howley PM, Munger K: Efficiency of binding the retinoblastoma protein correlates with the transforming capacity of the E7 oncoproteins of the human papillomaviruses. Proc Natl Acad Sci USA 1992, 89:4442-4446.

21. Toussaint-Smith E, Donner DB, Roman A: Expression of human papillomavirus type $16 \mathrm{E} 6$ and $\mathrm{E} 7$ oncoproteins in primary foreskin keratinocytes is sufficient to alter the expression of angiogenic factors. Oncogene 2004, 23:2988-2995.

22. Camus S, Menendez S, Cheok CF, Stevenson LF, Lain S, Lane DP: Ubiquitinindependent degradation of p53 mediated by high-risk human papillomavirus protein E6. Oncogene 2007, 26:4059-4070.

23. Thomas MC, Chiang CM: E6 oncoprotein represses p53-dependent gene activation via inhibition of protein acetylation independently of inducing p53 degradation. Mol Cell 2005, 17:251-264.

24. Patel D, Huang SM, Baglia LA, McCance DJ: The E6 protein of human papillomavirus type 16 binds to and inhibits co-activation by CBP and p300. EMBO J 1999, 18:5061-5072.

25. Zimmermann H, Degenkolbe R, Bernard HU, O'Connor MJ: The human papillomavirus type $16 \mathrm{E} 6$ oncoprotein can down-regulate p53 activity by targeting the transcriptional coactivator CBP/p300. J Virol 1999, 73:6209-6219.

26. Vogt M, Butz K, Dymalla S, Semzow J, Hoppe-Seyler F: Inhibition of Bax activity is crucial for the antiapoptotic function of the human papillomavirus E6 oncoprotein. Oncogene 2006, 25:4009-4015.

27. Bousarghin L, Touze A, Gaud G, lochmann S, Alvarez E, Reverdiau P, Gaitan J, Jourdan ML, Sizaret PY, Coursaget PL: Inhibition of cervical cancer cell growth by human papillomavirus virus-like particles packaged with human papillomavirus oncoprotein short hairpin RNAs. Mol Cancer Ther 2009, 8:357-365.

28. Butz K, Ristriani T, Hengstermann A, Denk C, Scheffner M, Hoppe-Seyler F: siRNA targeting of the viral E6 oncogene efficiently kills human papillomavirus-positive cancer cells. Oncogene 2003, 22:5938-5945.

29. Jonson AL, Rogers LM, Ramakrishnan S, Downs LS Jr: Gene silencing with siRNA targeting E6/E7 as a therapeutic intervention in a mouse model of cervical cancer. Gynecol Oncol 2008, 111:356-364.

30. Manning $G$, Whyte $D B$, Martinez $R$, Hunter $T$, Sudarsanam $S$ : The protein kinase complement of the human genome. Science 2002, 298:1912-1934.

31. Barford D: Molecular mechanisms of the protein serine/threonine phosphatases. Trends Biochem Sci 1996, 21:407-412.

32. Waterman MJ, Stavridi ES, Waterman JL, Halazonetis TD: ATM-dependent activation of p53 involves dephosphorylation and association with 14-33 proteins. Nat Genet 1998, 19:175-178.

33. Milczarek GJ, Chen W, Gupta A, Martinez JD, Bowden GT: Okadaic acid mediates p53 hyperphosphorylation and growth arrest in cells with wild-type p53 but increases aberrant mitoses in cells with nonfunctional p53. Carcinogenesis 1999, 20:1043-1048.

34. Goodarzi AA, Jonnalagadda JC, Douglas P, Young D, Ye R, Moorhead GB, Lees-Miller SP, Khanna KK: Autophosphorylation of ataxia-telangiectasia 
mutated is regulated by protein phosphatase 2A. EMBO J 2004 23:4451-4461

35. Ajay AK, Upadhyay AK, Singh S, Vijayakumar MV, Kumari R, Pandey V, Boppana R, Bhat MK: Cdk5 phosphorylates non-genotoxically overexpressed p53 following inhibition of PP2A to induce cell cycle arrest/apoptosis and inhibits tumor progression. Mol Cancer 2010, 9:204-219.

36. Zhang G, Sun L, Li Z, Si L, Song T, Huang C, Zhang W: HPV-16E6 can induce multiple site phosphorylation of p53. Oncol Rep 2009, 21:371-377.

37. Mi J, Bolesta E, Brautigan DL, Larner JM: PP2A regulates ionizing radiationinduced apoptosis through Ser46 phosphorylation of p53. Mol Cancer Ther 2009, 8:135-140.

38. Akutsu N, Shirasawa H, Asano T, Isono K, Simizu B: p53-Dependent and -independent transactivation by the E6 protein of human papillomavirus type 16. J Gen Virol 1996, 77:459-463.

39. Crook T, Fisher C, Masterson PJ, Vousden KH: Modulation of transcriptional regulatory properties of p53 by HPV E6. Oncogene 1994, 9:1225-1230.

40. Eichten A, Westfall M, Pietenpol JA, Munger K: Stabilization and functional impairment of the tumor suppressor $\mathrm{p} 53$ by the human papillomavirus type 16 E7 oncoprotein. Virology 2002, 295:74-85.

41. Cooper B, Schneider S, Bohl J, Jiang Y, Beaudet A, Vande PS: Requirement of E6AP and the features of human papillomavirus E6 necessary to support degradation of p53. Virology 2003, 306:87-99.

42. Jin Z, Wallace L, Harper SQ, Yang J: PP2A:B56, a Substrate of Caspase-3, Regulates p53-dependent and p53-independent Apoptosis during Development. J Biol Chem 2010, 285:34493-34502.

43. Bykov VJ, Issaeva N, Shilov A, Hultcrantz M, Pugacheva E, Chumakov P Bergman J, Wiman KG, Selivanova G: Restoration of the tumor suppressor function to mutant p53by a low-molecular-weight compound. Nat Med 2002, 8:282-288.

44. Singh S, Upadhyay AK, Ajay AK, Bhat MK: p53 regulates ERK activation in carboplatin induced apoptosis in cervical carcinoma: a novel target of p53 in apoptosis. FEBS Lett 2007, 581:289-295.

doi:10.1186/2045-3701-2-2

Cite this article as: Ajay et al: Human papillomavirus 18 E6 inhibits phosphorylation of p53 expressed in HeLa cells. Cell \& Bioscience 2012 2:2.

\section{Submit your next manuscript to BioMed Central and take full advantage of:}

- Convenient online submission

- Thorough peer review

- No space constraints or color figure charges

- Immediate publication on acceptance

- Inclusion in PubMed, CAS, Scopus and Google Scholar

- Research which is freely available for redistribution

Submit your manuscript at www.biomedcentral.com/submit 